Reference Library of Science and Invention to be formed as part of the British Museum Library, although housed as a separate unit. Scientific publications at present in the British Museum Library would be incorporated in the new Library. Care would be taken to safeguard the interest and convenience of those who use the present Patent Office Library, and they would be represented on an Advisory Committee to be set up when the new Library is brought into operation. Viscount de L'Isle welcomed this decision on behalf of the Trustees of the British Museum, and said that it would in due course make available to students and research workers the existing scientific resources of both the Patent Office and of the British Museum scientific collections in a compendious way and with the minimum of duplication.

\section{State Scholarships and Commonwealth Co-operation}

In the House of Lords on June 1, Lord Tweedsmuir asked the Government whether it would consider permitting up to 100 of the 2,000 State scholarships annually awarded in Britain to be tenable at Canadian or other Commonwealth universities if the recipient so elected. Lord Hailsham, replying for the Government, said that the Government would consider the matter in the light of the recommendations of the Anderson Committee. Asked by Lord Dalton to accelerate consideration of this question in view of the opportunities which Canadian and Australian universities can offer, Lord Hailsham agreed that it is a separate question from most of the contents of the Anderson Report, but thought that consultation with the Commonwealth Governments would be necessary before he could reply. Lord Casey sug. gested that the success of the proposal would depend on reciprocity between Commonwealth countries and the United Kingdom, and that into this consideration of cost and of available places would enter.

\section{Preservation of North Devon Countryside}

AN area of the North Devon countryside about 66 square miles in extent is to be protected by the confirmation by the Minister of Housing and Local Government of an order made by the National Parks Commission. The area includes the whole of the Hartland Peninsula and such places as Clovelly, Braunton Burrows, Croyde, Woolacombe and Combe Martin, near the western edge of the Exmoor National Park. The order, which is made by the National Parks Commission under the National Parks and Access to the Countryside Act, 1949, designates these parts of North Devon as "Areas of Outstanding Natural Beauty", not as a National Park. The responsibility for preserving and enhancing the natural beauty of the landscape rests with the local planning authority, Devon County Council. Government grants can be made at the rate of 75 per cent towards the cost of treating derelict land, tree planting and preservation, and removing disfigurements.

\section{Nature Conservation in Africa}

ANSWERING questions about Nature conservation in the Colonial territories in the House of Commons on June 2, the Secretary of State for the Colonies, Mr. Iain Macleod, welcomed the opportunity to reaffirm the Government's concern for wild life in Africa. Wild life conservation measures are, he said, continuously under review in the East and Central African territories, and in the past decade much has been done to establish and consolidate national parks and reserves. More use could be made of technical knowledge in developing the wild-life reserves, and the voluntary co-operation of the African populations is essential. The International Union for the Conservation of Nature, in consultation with other international agencies, is exploring the possibility of convening next year in Africa a conference on conservation. Mr. Macleod said that in a few weeks he would be able to study a detailed report by Dr. E. B. Worthington on his recent visit to Africa and the noed for further help.

\section{Journal of Child Psychology and Psychiatry}

A NEW journal which will be generally welcomed has been issued by the Association of Child Psychology and Psychiatry. It is the Journal of Child Psychology and Psychiatry and Allied Disciplines, and is published

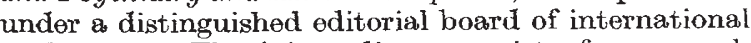
authorities. The joint editors consist of a research psychologist, psychiatric social worker and a wellknown physician in child-psychiatry, Dr. Emanuel Miller, while the corresponding editors are Prof. Milton Senn, Department of Pediatrics, Yale University, and P. H. Mursen, Department of Psychology, University of California. The Journal is attractively produced and the first issue (Vol. I, No. 1 (January 1960). Pp. 98. Published quarterly. Subscription rates: To members of the Association of Child Psychology and Psychiatry 63s. per annum, inclusive of membership. To private individuals 105s. (15 dollars) per annum. To libraries and institutions 140s. (20 dollars) per volume. London and New York : Pergamon Press, 1960) contains articles which are refreshingly free from the jargon so beloved by students of human behaviour. The standard is set in the first article by Dr. Miller, who traces the origins of child-psychiatry, while Prof. Leo. Karner (Johns Hopkins University) shows that behaviour symptoms do not always indicate psychopathology; the clarity and brevity of his writing has much to commend itself to his fellow-American psychiatrists. Other articles deal with the effects of early deprivation and separation on children, manic-depressive psychosis in childhood, a gap in the structure of general psychology and a description of the training provided in childpsychotherapy at the Tavistock Clinic. Provided that the new journal can maintain this standard and keep itself free from psychiatric expertize, it could prove as useful to teachers and intelligent parents as to the professional child-psychiatrist and psychologist for whom it is intended.

\section{Pavlov Journal of Higher Nervous Activity}

This journal has been added to the list of Russian journals which are being published in English trans. lation. By arrangement with the Soviet authorities, 'rush' copies of the original journal and its illustra. tions are to be made available, so that the delay in publication of the translation ean be made as short as possible. 'The first issue of the 1959 volume contains 18 original communications, together with a short review of work carried out in the United States of America during the years 1954-57 on conditioned reflexes in animals. There is an obituary of the eminent Russian physiologist, L. A. Orbeli (Vol. 9. No. 1. Translated from the Russian. Pp. 140. Published bi-monthly. Approximately 1,000 pages per volume. Annual subscription 210s.; 30 dollars. London and New York: Pergamon Press, 1960). 